\title{
Article \\ Microbial Community Composition in Thermal Waters from the Lindian Geothermal Field (Songliao Basin, North-Eastern China)
}

\author{
Fengtian Yang ${ }^{1,2} \mathbb{D}$, Dong Li ${ }^{1,2} \mathbb{D}$, Xuejun Zhou ${ }^{3}$, Tao Zhan ${ }^{3}$, Yongfa Ma ${ }^{3}$, Xu Wang ${ }^{3}$, Junling Dong ${ }^{3}$, Ling Liu ${ }^{3}$, \\ Yujia Shi ${ }^{1,2}$ and Yujuan $S u^{1,2, *}$
}

check for

updates

Citation: Yang, F.; Li, D.; Zhou, X.; Zhan, T.; Ma, Y.; Wang, X.; Dong, J.; Liu, L.; Shi, Y.; Su, Y. Microbial Community Composition in Thermal Waters from the Lindian Geothermal Field (Songliao Basin, North-Eastern China). Water 2022, 14, 632. https:// doi.org/10.3390/w14040632

Academic Editors: Xianfang Song, Lihu Yang, Yanlong Kong and Stefano Amalfitano

Received: 8 November 2021 Accepted: 14 February 2022 Published: 18 February 2022

Publisher's Note: MDPI stays neutral with regard to jurisdictional claims in published maps and institutional affiliations.

Copyright: (c) 2022 by the authors. Licensee MDPI, Basel, Switzerland. This article is an open access article distributed under the terms and conditions of the Creative Commons Attribution (CC BY) license (https:// creativecommons.org/licenses/by/ $4.0 /)$.
1 Key Laboratory of Groundwater Resources and Environment, Ministry of Education, Jilin University, Changchun 130021, China; yangfengtian@jlu.edu.cn (F.Y.); jluld96@126.com (D.L.); shiyj1244060668@126.com (Y.S.)

2 Jilin Provincial Key Laboratory of Water Resources and Environment, Jilin University, Changchun 130021, China

3 The Institute of Ecological Geology Survey and Research of Heilongjiang Province, Harbin 150030, China; 13766893593@163.com (X.Z.); hljzhantao@163.com (T.Z.); 80902601@foxmail.com (Y.M.); compasseagle@163.com (X.W.); junling1022@foxmail.com (J.D.); 51742586@foxmail.com (L.L.)

* Correspondence: suyj15@mails.jlu.edu.cn

\begin{abstract}
Geothermal systems represent discrete and relatively homogenous habitats for extremophiles; investigation into the microbial community is key to revealing the geochemical environment and the geochemical evolution of fluids in geothermal reservoirs. The reservoir of the Lindian geothermal field in Northeast China, is highly reducing and rich in methane, but the pathways of methane generation and the related microbial community structure are still unclear. In this research, five thermal water samples were collected and tested, and the microbial community structure and diversity were analyzed. The results show that in the sandstone reservoir belonging to the lowtemperature (reservoir temperature $<90^{\circ} \mathrm{C}$ ) brackish water (total dissolved solids concentration between 1000 and $10,000 \mathrm{mg} / \mathrm{L}$ ) environment, the richness of the microbial community is relatively high. The microbial community structure is different from other geothermal systems reported but similar to that of oilfields, which may be related to the highly reducing geochemical environment with abundant organic matter. According to the analysis of archaeal function, the biogas production in the Lindian geothermal field is dominated by hydrogen nutrition type methane production, while the $\mathrm{H}_{2}$ reducing methylamine type methane production is secondary, and results of Pearson correlation show that the archaeal communities are more strongly correlated to physicochemical factors than the bacterial communities.
\end{abstract}

Keywords: thermophilic bacteria and archaea; microbial community; methanogens; Lindian geothermal field

\section{Introduction}

Microorganisms are the main form of life in subsurface ecosystems. The groundwater environment has nutrients, water, $\mathrm{pH}$, osmotic pressure, temperature and other conditions needed for microbial growth and forms a special living habitat for microorganisms. Meanwhile, microorganisms are also an important driving force in the hydrogeochemical evolution of geofluids [1,2]. Geothermal systems represent discrete and relatively homogenous habitats for extremophiles. These extremophiles can live in the thermoboitic environments that are above the 'thermophile boundary' of 55 to $60{ }^{\circ} \mathrm{C}$ [3], and participate in many redox reactions, such as sulfate and nitrate reduction, hydrogen oxidation and methanogenesis [4,5], which shapes the water chemistry across time and space. Therefore, an investigation into the composition of the microbial communities in geothermal systems is key to reveal the mechanism of geochemical evolution in geothermal reservoirs, and 
moreover, predict the water-rock interactions mediated by microorganisms under human activities, such as reservoir clogging during geothermal reinjection and $\mathrm{CO}_{2}$ sequestration in deep saline aquifers $[6,7]$.

Recent studies have shown that the structure of microbial communities evolves across time and space, mainly driven by environmental selection and dispersal limitation $[8,9]$. However, the relative contribution of these ecological factors is still in debate, with different findings reported across terrestrial and marine water bodies [10]. Among terrestrial water bodies, shallow groundwater is the most studied [11,12]. These studies suggest that the microbial community composition is influenced predominantly by substrates (e.g., minerals and organic matter) and water chemistry [13-15]. As the environment of geothermal reservoirs is under relatively high temperature, pressure and salinity, and usually more oligotrophic with respect to shallow groundwater aquifers, the environmental parameters controlling the community structure are different. Most studies have implied that temperature and $\mathrm{pH}$ are the primary drivers of bacterial and archaeal communities in these ecosystems, and other geochemical variables, especially substrates, such as hydrogen and nitrogen, may also contribute to community structure [10]. However, among the existing studies on geothermal systems, the microbial communities of relatively high-temperature hot springs, such as Yellowstone National Park in the United States, Taupo Volcanic Zone (TVZ) in New Zealand, Padang Germin hot springs in Indonesia, and Tengchong hot springs in Yunnan in China, are the most studied [16-21], whereas low-temperature geothermal systems are less investigated, a lack of cases has hindered a comprehensive understanding of the microbial biogeography and the influencing environmental parameters.

The Lindian geothermal field located in nothern Songliao Basin, Northeast China, is a typical low-temperature geothermal system. Geothermal fluids in the reservoir are abundant in methane. Previous studies have suggested that the methane is mainly biogenic, i.e., from the decomposition of immature organic matter by microorganisms in a reducing environment [22,23], but the characteristics of the microbial communities have not been fully studied. Therefore, the present research collected representative geothermal water samples from the Lindian geothermal field and performed microbial community analysis of the bacterial and archaeal population (16S rRNA gene amplicon sequencing) and gene function prediction based on the FAPROTAX database; then, analyzed the structure and diversity of the microbial communities, and explained the genesis of methane. This study will enrich the understanding of the composition and habitat features of the microbial communities in low-temperature geothermal reservoirs.

\section{Materials and Methods}

\subsection{Study Area}

The Lindian geothermal field is located in the Songliao Basin, Northeast China, covering an area of ca. $3500 \mathrm{~km}^{2}$ (Figure 1). The area was the sedimentary center of the basin in the Mesozoic and Cenozoic, where a series of fluvial-lacustrine sediments was deposited greater than $3000 \mathrm{~m}$ in thickness, including the Craterous, Lower-Middle Eogene and Quaternary. The main geothermal reservoirs consist of part of the Lower and Upper Craterous sandstones; the burial depth of the roof and bottom of the reservoirs are 980-1500 m and 1670-2430 m, respectively. The reservoir temperature falls between 47.4 and $89.0^{\circ} \mathrm{C}$, thus belonging to a low-temperature geothermal system. As some strata constituting the reservoir were deposited under a deep-water environment, the reservoir is abundant in biogas source rocks [24]. Investigation of the geothermal fluids has shown that the main gas component is methane, which accounts for $53.7-95.1 \%$ of the dissolved gas in volume [25]. 


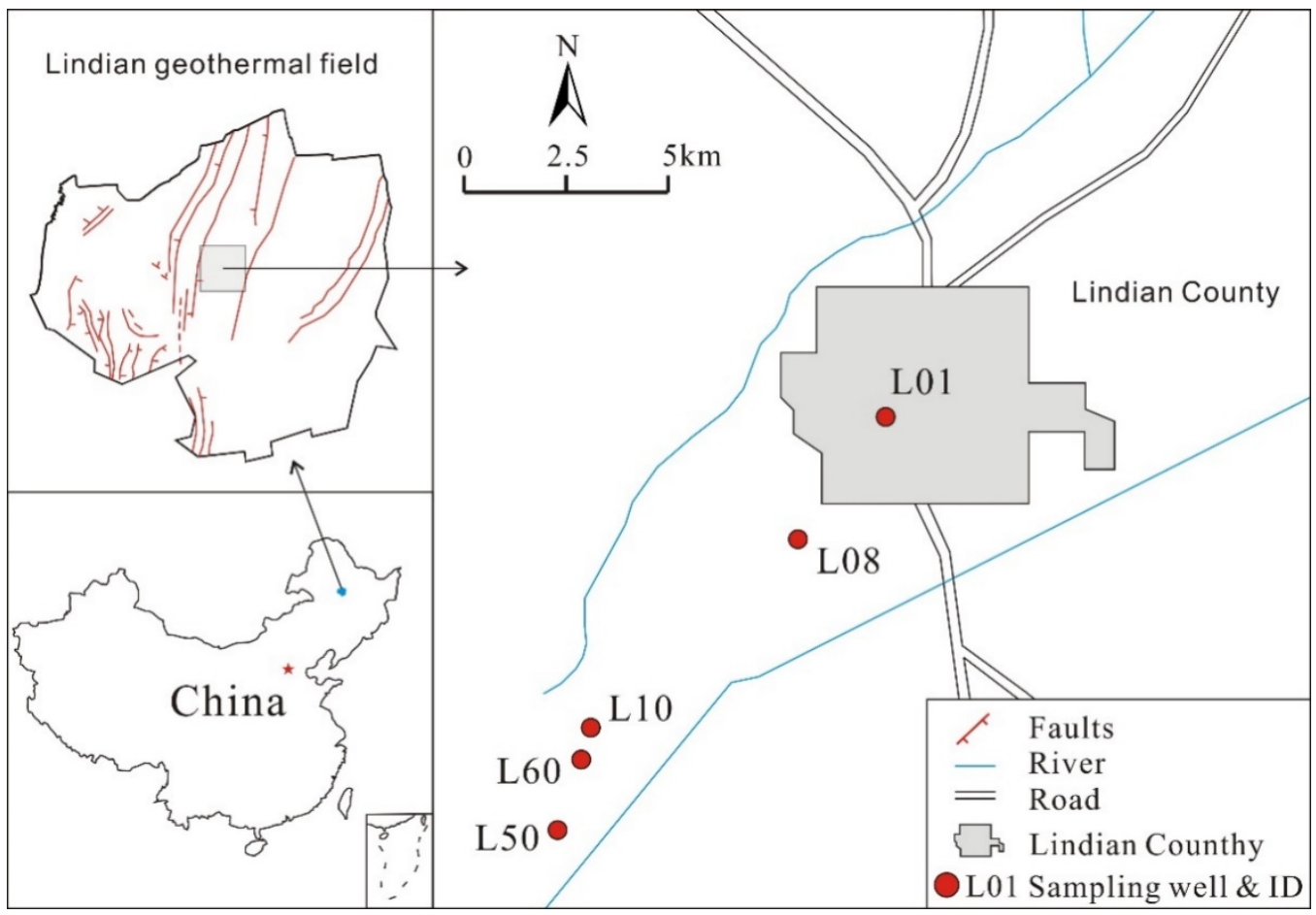

Figure 1. Location of the Lindian geothermal field and sampling wells.

\subsection{Sampling and Analysis}

The field campaign was carried out in January 2019. Five geothermal wells in operation were chosen for microbial sampling (Figure 1). These wells are located in the center of the geothermal field, and the profile from well L01, L08, L10, L60 to L50 are consistent with the regional flow path of the thermal water. In total 5 water samples (L01, L08, L10, L60 and L50) were collected.

The water samples were analyzed both for water chemistry and microbial communities. Water temperature (T), $\mathrm{pH}$ and total dissolved solids (TDS) were measured in situ using a portable multi-parameter (Hach HQ40D, Hach, Loveland, CO, USA), the resolutions are $0.3^{\circ} \mathrm{C}, 0.01$ and $0.1 \mathrm{mg} / \mathrm{L}$, respectively. Water samples for $\mathrm{SO}_{4}{ }^{2-}$ analysis were collected using $50 \mathrm{~mL}$ higher-density polyethylene (HDPE) bottles after filtration with a sterile $0.22 \mu \mathrm{m}$ membrane filter and were measured with Dionex DX-500 ion chromatography (Dionex, Sunnyvale, CA, USA), with a precision better than $5 \%$. The sampling method for rare earth elements (REEs) was similar to that of $\mathrm{SO}_{4}{ }^{2-}$, except for that the water samples were acidified by $\mathrm{HNO}_{3}$ to $\mathrm{pH}<2$ and measured using NexIONTM 300D ICP-MS (PerkinElmer, Waltham, MA, USA) with a precision better than $3 \%$. Total organic carbon (TOC) samples were collected using $50 \mathrm{~mL}$ bottles and measured with Shimadzu TOC-L $\mathrm{CPH}$ Analyzer (Shimadzu, Nishinokyo Kuwabara-cho, Kyoto, Japan), with a detection limit of $4 \mu \mathrm{g} / \mathrm{L} . \delta^{13} \mathrm{C}_{\mathrm{DIC}}\left(\delta^{13} \mathrm{C}\right.$ of dissolved inorganic carbon) samples were collected using $500 \mathrm{~mL}$ HDPE bottles avoiding any air contamination and were measured with an Isoprime 100 stable isotope ratio mass spectrometer (Isoprime, Cheadle Hulme, Cheadle, UK). The results were reported in \%o relative to the standard VPDB (Vienna Pee Dee Belemnite) with a precision better than $0.1 \%$. These measurements were carried out in the Measurement Science and Experiment Center, Jilin University.

The microbial samples were collected using $18 \mathrm{~L}$ high-temperature resistant sterile plastic buckets, transported to the laboratory and filtered onto polytetrafluoroethylene membranes with a pore size of $0.22 \mu \mathrm{m}$; then the membranes were frozen and sent to Shanghai Sangong Biotech Co., Ltd. for microbial community analysis. The samples were analyzed by Illumina Miseq (Illumina, San Diego, CA, USA) sequencing. Genomic DNA was extracted using an E.Z.N.A ${ }^{\circledR}$ Mag-Bind Soil DNA Kit (Omega Bio-Tec, Doraville, GA, 
USA). Two rounds of polymerase chain reaction (PCR) amplification were performed for the bacteria. The first round of amplification with bacterial 16S rDNA genes (V3-V4) from the isolated DNA was performed using the primers 341F (CCTACGGGNGGCWGCAG) and 805R (GACTACHVGGGTATCTAATCC) combined with the Miseq sequencing, while compatible primers of PCR were introduced in the second round of amplification. The PCR amplification of archaea included three rounds. In the first round, the isolated DNA was amplified with M-340F (CCCTAYGGGGYGCASCAG) and GU1ST-1000R (GGCCATGCACYWCYTCTC) primers; the second round of amplification with archaea $16 \mathrm{~S}$ rDNA genes (V3-V4) was conducted with the primers 349F (GYGCASCAGKCGMGAAW) and 806R (GGACTACVSGGGTATCTAAT), and the third round of amplification was the same as the second round of bacterial amplification. The DNA after PCR was then purified by Agencourt Ampure XP Magnetic Beads (Beckman Coulter, Indianapolis, IN, USA) and quantified by a Qubit 2.0 $0^{\mathrm{TM}}$ DNA detection kit (Thermo Fisher Scientific, Waltham, MA, USA). The purified amplicons were sequenced on an Illumina MiSeq platform. The bioinformation of raw DNA data was analyzed based on the database of Ribosomal Database Project (RDP), Silva and the National Center for Biotechnology Information (NCBI). The obtained DNA reads were then clustered to operational taxonomical units (OTUs) with $97 \%$ similarity.

\section{Results and Discussion}

\subsection{Characteristics of Geothermal Reservoir Environment}

The hydrochemistry type of the geothermal waters is $\mathrm{HCO}_{3} \cdot \mathrm{Cl}-\mathrm{Na}$. The depth of the sampling wells is $1800-2718 \mathrm{~m}$, the reservoir temperature predicted by the non-steam loss non-mixing quartz geothermometer proposed by Fournier [26] is 72.9-89.0 ${ }^{\circ} \mathrm{C}$ [27], while the $\mathrm{pH}$ is $8.14-8.93$, TDS is $1440-1699 \mathrm{mg} / \mathrm{L}$, TOC is $323.4-477.1 \mathrm{mg} / \mathrm{L}$ and ${ }^{13} \mathrm{C}_{\text {DIC }}$ ranges from -12.11 to $-8.07 \%$ VPDB (Table 1 ).

Table 1. Chemical characteristics of the thermal waters.

\begin{tabular}{|c|c|c|c|c|c|c|c|c|c|}
\hline $\begin{array}{c}\text { Sample } \\
\text { ID }\end{array}$ & $\begin{array}{l}\text { Depth } \\
\text { (m) }\end{array}$ & $\begin{array}{c}\mathrm{T}^{*} \\
\left({ }^{\circ} \mathrm{C}\right)\end{array}$ & $\mathrm{pH}$ & $\begin{array}{c}\text { TDS } \\
(\mathrm{mg} / \mathrm{L})\end{array}$ & $\begin{array}{c}\text { TOC } \\
(\mathrm{mg} / \mathrm{L})\end{array}$ & $\begin{array}{c}{ }^{13} C_{\text {DIC }} \\
(\% \circ \text { VPB })\end{array}$ & $\mathrm{Ce} / \mathrm{Ce}^{*}$ & $\mathrm{Eu} / \mathrm{Eu}^{*}$ & $\begin{array}{l}\mathrm{SO}_{4}{ }^{2-} \\
(\mathrm{mg} / \mathrm{L})\end{array}$ \\
\hline L01 & 2718 & 89.0 & 8.17 & 1563 & 323.4 & -9.60 & ND & 10.95972 & 0.101 \\
\hline L08 & 1802 & 77.6 & 8.40 & 1440 & 477.1 & -9.28 & 0.539 & 6.467552 & 0.053 \\
\hline L10 & 2002 & 72.9 & 8.93 & 1544 & 367.4 & -10.36 & ND & 6.818943 & 0.189 \\
\hline L50 & 2250 & 78.9 & 8.14 & 1699 & 417.6 & -8.07 & ND & 7.392759 & 0.189 \\
\hline L60 & 2000 & 84.3 & 8.20 & 1670 & 441.2 & -12.11 & 0.295 & 5.778223 & 0.466 \\
\hline
\end{tabular}

Rare earth elements Ce and Eu in groundwater are sensitive to the redox environment. Groundwater environments different in redox state often show positive or negative anomalies of Eu and Ce normalized against North American Shale Composite (NASC) [28-30], i.e., the concentration of $\mathrm{Eu}$ or $\mathrm{Ce}$ in the sample is higher or lower than that in NASC $\left(\mathrm{Eu}^{*}\right.$ or $\left.\mathrm{Ce}^{*}\right)$, respectively. Generally, $\mathrm{Eu} / \mathrm{Eu}^{*}<1$ or $\mathrm{Ce} / \mathrm{Ce}^{*}>1$ indicates an oxidizing environment, while $\mathrm{Eu} / \mathrm{Eu}^{*}>1$ or $\mathrm{Ce} / \mathrm{Ce}^{*}<1$ represents a reducing environment [31]. As all the thermal water samples collected show $\mathrm{Ce} / \mathrm{Ce}^{*}<1$ and $\mathrm{Eu} / \mathrm{Eu}^{*}$ much higher than 1 (Table 1), indicating that the geochemical environment of the geothermal reservoir is highly reducing.

\subsection{Microbial Community Structure}

\subsubsection{Bacterial Community Structure}

In the thermal water samples, Proteobacteria (average abundance 94.97\%) and Bacteroidetes $(1.82 \%)$ are the dominant phyla, among which Gammaproteobacteria $(78.75 \%)$ dominates, followed by Alphaproteobacteria $(11.41 \%)$ and Betaproteobacteria $(4.86 \%)$ (see Figure S1). In previous studies, Proteobacteria usually do not have absolute advantage over the other phyla in most low-temperature geothermal fields. For example, the Firmicutes 
and Proteobacteria in the deep karst-fissure geothermal reservoir in the Xiongan New Area account for $38.70 \%$ and $37.61 \%$ of the microorganism, respectively [32], while Bacteroidetes are dominant (ca. 80\%) in the Unkeshwar hot springs of India (water temperature $42-60^{\circ} \mathrm{C}$ ) [33], Actinobacteria and Aquificae are the dominant bacteria in the hot springs in Coffee Pot of Yellowstone National Park, USA (water temperature 39-74 ${ }^{\circ} \mathrm{C}, \mathrm{pH}$ 5.8-6.9), while Proteobacteria and Aquificae accounts for $34.2 \%$ and $31 \%$ of total average relative abundance in TVZ, respectively [10]. Thus, the absolute domination of Proteobacteria in the thermal waters from Lindian is not very common, which probably relates to the high organic matter content (143 g/ kg on average) in the reservoir rock and thermal water [27].

At the genus level, Acinetobacter (average abundance 73.80\%), Novosphingobium (6.21\%), Pseudomonas (2.91\%), Alphaproteobacteria, Rhizobium (1.46\%), Aquabacterium (1.40\%), Brevundimonas (1.37\%) and Hydrogenophaga (1.03\%) dominate, among which Acinetobacter is the dominant species, and Proteobacteria are the only bacterial species with an abundance greater than $1 \%$ at the genus level (Figure 2).

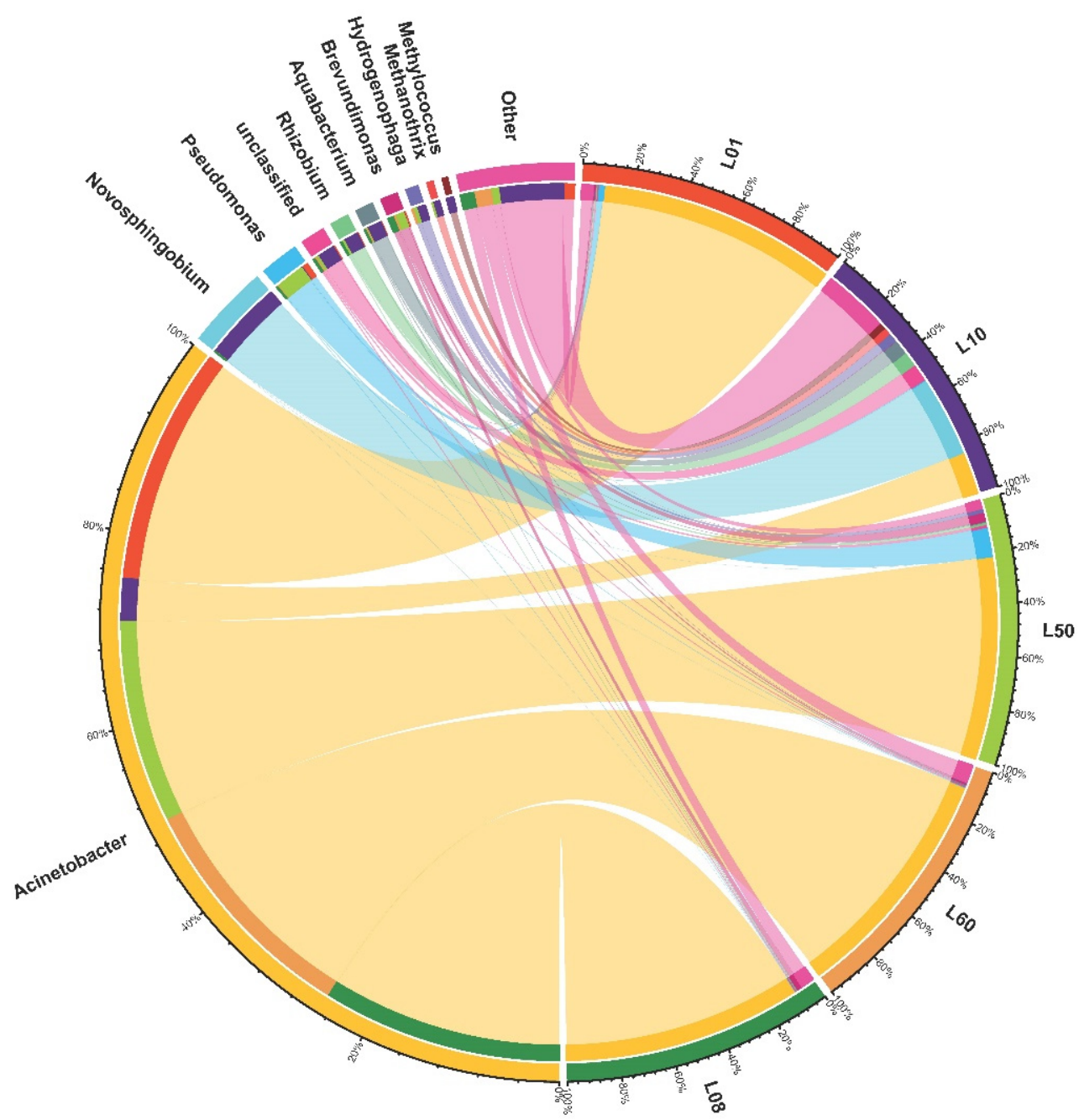

Figure 2. Relationship between samples and taxa of bacterial communities at the genus level.

Acinetobacter and Pseudomonas are found abundant in oil reservoirs and are currently known as the genera with hydrocarbon degradation function [34], which are aerobic mesophilic bacteria [35,36], e.g., Acinetobacter are the dominant taxa (19-85\%) in the Daqing Oilfield adjacent to the Lindian geothermal field [1], indicating that the reservoir environment is to some extent similar to oil reservoirs, such as similar temperature range and organic matter content in reservoir rocks. 


\subsubsection{Archaeal Community Structure}

The archaeal community (abundance $>1 \%$ ) is mainly composed of Euryarchaeota (average abundance $79.12 \%)$, Thaumarchaeota $(8.85 \%)$ and Woesearchaeota $(2.83 \%)$. Among them, Euryarchaeota dominates. Eurycota, traditionally known as methanogens, are typically involved in sulfur, nitrogen and iron cycling in addition to hydrocarbon conversion [37]. The archaeal community in the deep karst geothermal reservoir in the Xiongan New Area is dominated by Euryarchaeota and Crenarchaeota (average abundance 93\%) [38]. The archaeal taxa with abundance greater than $1 \%$ mainly include Methanosarcinales $(48.66 \%)$, Methanomicrobiales (16.43\%), Nitrososphaerales (8.78\%), Methanobacteriales $(7.60 \%)$, Methanomassillicoccales $(4.85 \%)$ and Woesearchaeota $(2.83 \%)$ (Figure S2).

At the genus level, the archaeal community (abundance $>1 \%$ ) mainly includes Methanothrix (average abundance 35.62\%), Methanosarcina (10.97\%), Methanocystococcus (10.32\%), Methanothrix (35.62\%), Methanosarcina (10.97\%), Methanoculleus (10.32\%), Nitrososphaera (8.78\%), Methanomassiliicoccus (4.85\%), Methanobacterium (3.67\%) and Methanospirillum (3.29\%), Methanothermobacter (2.17\%), Woesearchaeota Incertae Sedis Ar16 (2.13\%), Methanomethylovorans (1.95\%), Methanosphaerula (1.28\%) and Methanobrevibacter (1.07\%). Except for Woesearchaeota Incertae Sedis AR16 and Nitrososphaera, which are part of a branch of ammonia-oxidizing archaea (AOA) generated during microbial nitrification [39], all the archaea with an abundance greater than $1 \%$ belong to Eurycota (Figure 3 ).

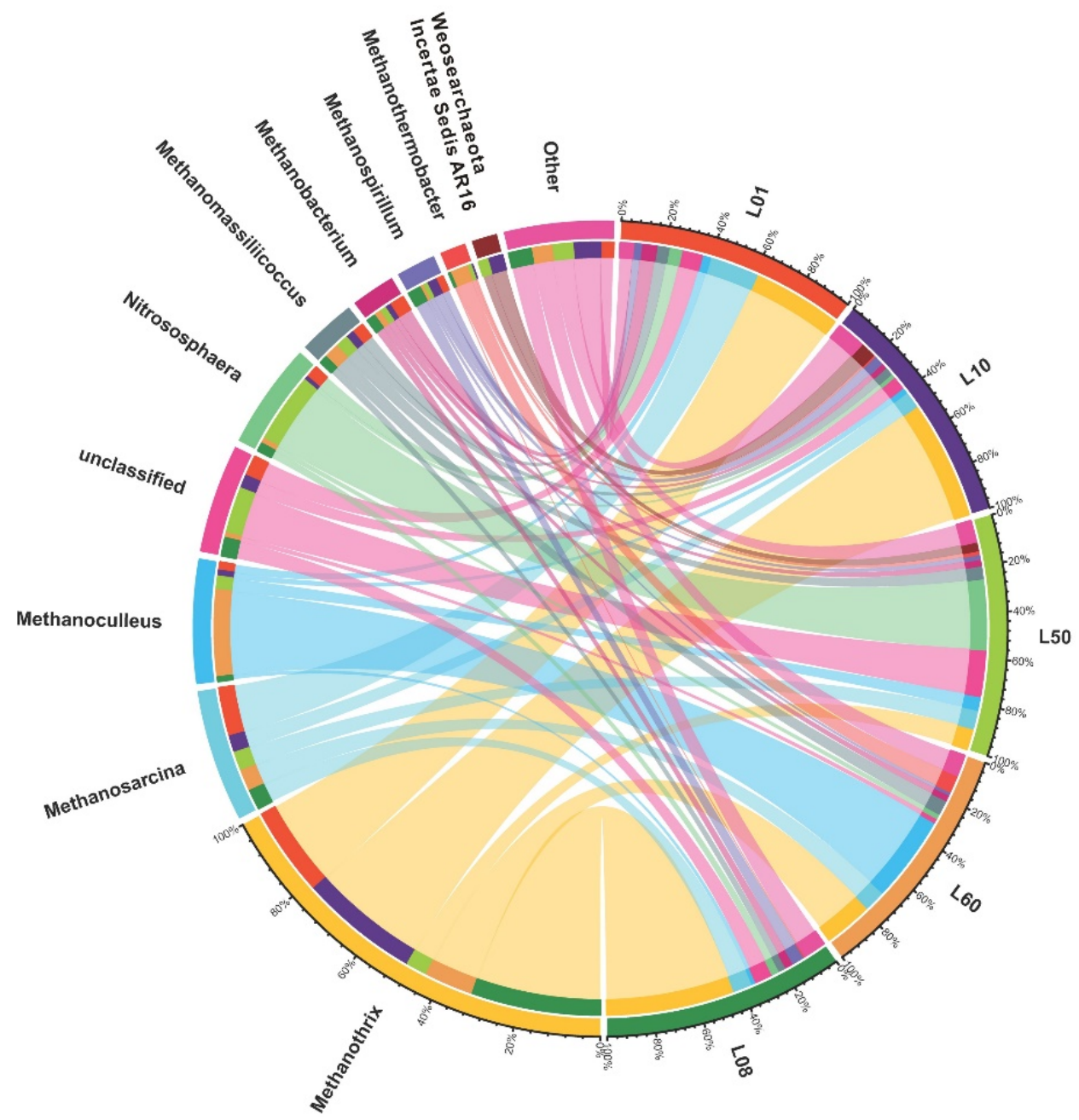

Figure 3. Relationship between samples and taxa of archaeal communities at the genus level. 


\subsection{Mechanism of Methanogenesis}

The results show that methanogens dominate the archaeal community in the Lindian geothermal field. The existence of methanogens indicates that the groundwater environment is extremely reducing. Methanogens combine $\mathrm{H}_{2}$ and $\mathrm{CO}_{2}$ to drive energy metabolism and produce $\mathrm{CH}_{4}$ as a metabolite. Methanogens use an ancient carbon dioxide fixation pathway called the reductive acetyl-coA pathway [40]. Methanation is the final step in the anaerobic fermentation process. In this process, acetic acid and methylamine, $\mathrm{H}_{2}$ and $\mathrm{CO}_{2}$, and methylamine and methanol are transformed into $\mathrm{CH}_{4}$ and $\mathrm{CO}_{2}$ through acetoclastic methanogens, hydrogenotrophic methanogenesis and methylotrophic methanogenesis, respectively [41]. Methane production is a strictly anaerobic process occurring in sulfatedeficient environments; methanogenic activity occurs only in the case when sulfate is depleted or at extremely low concentrations. As the concentration of $\mathrm{SO}_{4}{ }^{2-}$ in the reservoir of the thermal water is very low in the Lindian geothermal field (Table 1), the reservoir environment is highly sulfate deficient, thus is favorable for methanogenesis. Moreover, the methanogen community structure is another important factor affecting the intensity of methane production. According to the analysis of available substrates at methanogen level in the study area (Table 2), the most available substrates of methanogens with high abundance in the reservoir are $\mathrm{H}_{2}$ and $\mathrm{CO}_{2}$, which also confirms that hydrogenotrophic methanogenesis is the primary pathway.

Table 2. Characteristics of the methanogens at order level [42].

\begin{tabular}{ccccc}
\hline Methanogens & Methanobacteriales & Methanomicrobiales & Methanosarcinales & Methanomassiliicoccales \\
\hline Representatives & $\begin{array}{c}\text { Methanobacterium bryanlii, } \\
\text { Methanobrevibacter wolfeii, } \\
\text { Methanosphaera stadtmanae }\end{array}$ & $\begin{array}{c}\text { Methanoculleus } \\
\text { bourgensis, } \\
\text { Methanogenium cariaci }\end{array}$ & $\begin{array}{c}\text { Methanosarcina barkeri, } \\
\text { Methanosaeta concilii }\end{array}$ & $\begin{array}{c}\text { Methanomassiliicoccus } \\
\text { luminyensis }\end{array}$ \\
\hline $\begin{array}{c}\text { Substrate } \\
\mathrm{H}_{2}+\mathrm{CO}_{2} \text { (formic acid, } \mathrm{CO}, \\
\text { ethyl alcohol, methyl } \\
\text { alcohol) }\end{array}$ & $\begin{array}{c}\mathrm{H}_{2}+\mathrm{CO}_{2} \text {, formic acid } \\
\text { (ethyl alcohol) }\end{array}$ & $\begin{array}{c}\text { Methanol, } \\
\text { methylamine, acetic } \\
\text { acid }\left(\mathrm{H}_{2}+\mathrm{CO}_{2}\right)\end{array}$ & $\begin{array}{c}\mathrm{H}_{2}+\text { methylamine } \\
(\text { methyl alcohol })\end{array}$ \\
\hline $\begin{array}{c}\text { Temperature range } \\
\left({ }^{\circ} \mathrm{C}\right)\end{array}$ & $15-97$ & $0-60$ & $2-70$ & 37 \\
\hline
\end{tabular}

Based on the FAPROTAX database, the bacterial community function is predicted. The results show that the bacterial community functions with the highest abundance are chemoheterotrophy, aerobic_chemoheterotrophy, animal_parasites_or_symbionts, human_pathogens and aromatic_compound_degradation (Figure 4). The main function is to degrade macromolecular organic matters, i.e., organic matter is broken down by fermentation bacteria into substrates available to methanogens (e.g., hydrogen, carbon dioxide, Acetic acid, methanol and dimethyl sulfide), which is also identified by the negative correlation between archaeal richness and ${ }^{13} \delta \mathrm{C}_{\mathrm{DIC}}$, as ${ }^{13} \delta \mathrm{C}_{\mathrm{DIC}}$ is depleted due to fractionation during the decomposition of organic matters [43].

The predicted functions of the archaeal community with the highest abundance are methanogenesis, hydrogenotrophic_methanogenesis and methanogenesis by $\mathrm{CO}_{2}$ reduction with $\mathrm{H}_{2}$ (Figure 5). It can be seen that the predicted abundance of methane production function of $\mathrm{CO}_{2}$ reduction by $\mathrm{H}_{2}$ is higher, while the methanogenesis by the reduction of methyl compounds with $\mathrm{H}_{2}$ is secondary (abundance 1.9\%). This is consistent with the reservoir lithology, which is mainly sandstone and mudstone rich in organic matters, thus facilitating $\mathrm{H}_{2}$ and $\mathrm{CO}_{2}$ production and hydrogenotrophic methanogenesis [44]. 


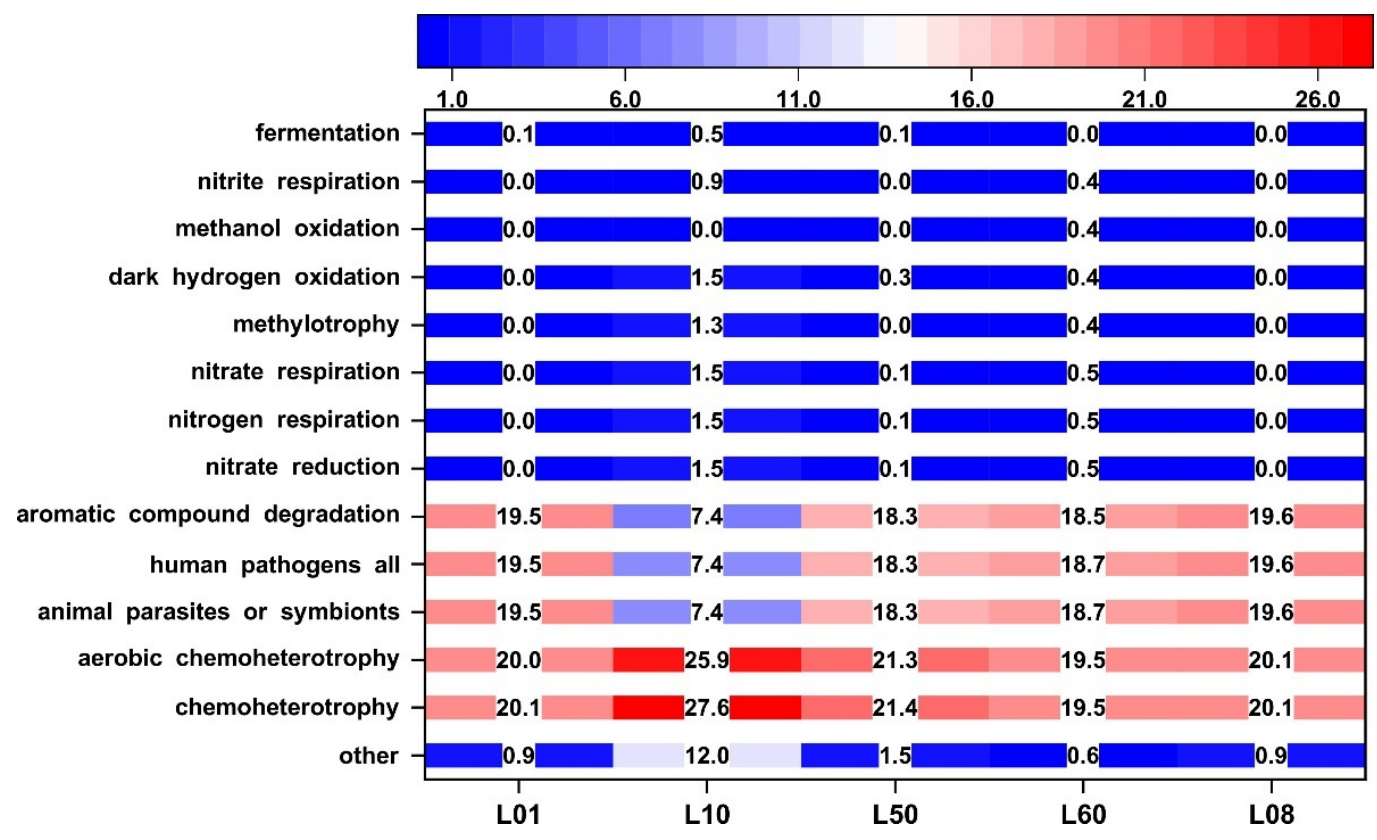

Figure 4. Heat map illustrating function prediction of bacterial community. The numbers are the abundance of the functions in \%.

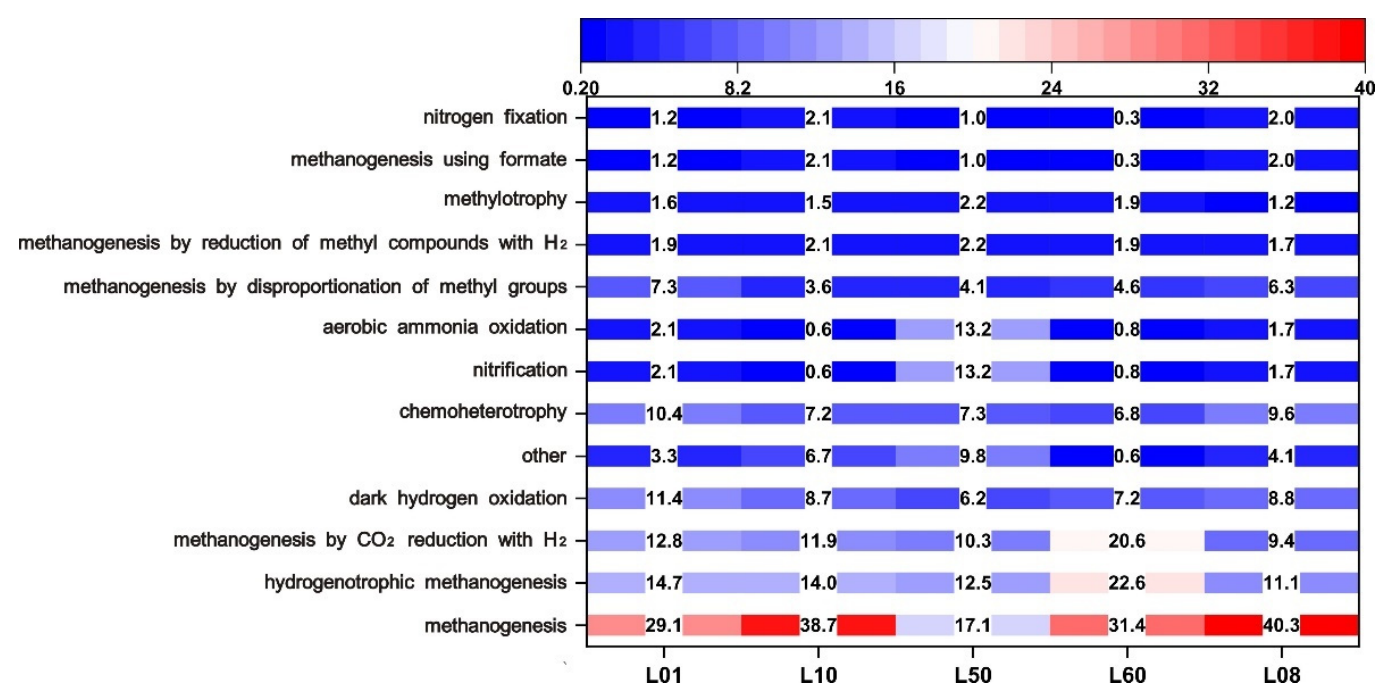

Figure 5. Heat map illustrating function prediction of archaeal community. The numbers are the abundance of the functions in \%.

\subsection{Microbial Diversity}

Alpha diversity analysis is conducted to characterize the abundance and diversity of microbial communities, including a series of statistical indexes, such as Shannon, Simpson, Chao1, ACE indexes and Coverage, among which Shannon, Simpson indexes and Coverage are used to reveal the distribution diversity of the microbial communities. A larger Shannon index indicates a higher community diversity, while a larger Simpson index indicates a lower community diversity; Coverage refers to the coverage of each sample library. The higher the value is, the lower the probability that the sequence in the sample is not detected. This index actually reflects to what extent the sequencing result represents the real composition of the sample; Chao1 and ACE indexes are used to estimate the number of OTUs in the community, which can reflect the abundance of the microbial community. Moreover, Chao1 is often used to estimate the total number of species in the microbial community. Higher Chao1 and ACE indices indicate higher community richness. 
A total of 677,437 original sequences were obtained by high-throughput sequencing of five samples in this study, and 21,377 OTUs were generated, among which 8298 OTUs were generated by the archaeal community (see Table S1), and 13,079 OTUs by the bacterial community (see Table S2), accounting for $32 \%$ and $68 \%$ of the whole microbial community, respectively. Generally, OTUs of geothermal waters are low, e.g., the OTUs of the thermal waters are 284-564, 49-2997, 224 and 2398 from the Xiongan New Area [45], TVZ [10], the Western Plain of Romania [46] and Sri Lanka [47], respectively. Thus, the total number of microbial taxa in thermal waters from the Lindian geothermal field is remarkably abundant, indicating abundant substrates, i.e., the high organic matter contents in the reservoir (Table 1).

It is generally believed that in the geothermal environment of low temperatures $\left(50-90^{\circ} \mathrm{C}\right)$, microbial communities are dominated by bacteria, while archaea may only be dominant when the temperature is higher than $90{ }^{\circ} \mathrm{C}$ [48]. In this research, the reservoir temperatures of the sampling wells are $72.9-89.0^{\circ} \mathrm{C}$, and the sequencing result shows that archaea are not dominant, which is consistent with common findings, but the proportion of archaea in the microbial communities is much higher than those in most cases reported in previous studies. For example, in the deep groundwater of Yinchuan (sampling depth 230-600 m), the proportion of archaea is $0.84 \%$ [49], while in the Xiongan New Area, the proportion is $2.5 \%$ (sampling depth $1500-3853 \mathrm{~m}$, temperature $60-83{ }^{\circ} \mathrm{C}$, slightly alkaline, brackish thermal water) [38], and ca. $0.4 \%$ in TVZ (temperature range of hot springs 13.9-100. $6^{\circ} \mathrm{C}$ ) [10]. This is unusual, which is probably related to the specific geochemical environment of the reservoir, such as high organic matter content (TOC up to $477.1 \mathrm{mg} / \mathrm{L}$ ) and highly reducing (dissolved oxygen $<2 \mathrm{mg} / \mathrm{L}$ ) [27].

Biostatistical analysis shows that the community coverage of the samples is all greater than $95 \%$, indicating that the sequencing amount can represent the composition of the microbial community. The Chao1 index of the samples ranges from 17,465.49 to $80,566.93$, while the Shannon and Simpson indexes ranges are 0.79-3.49 and 0.13-0.81, respectively (see Table S3); the Chao1 index of the archaea communities ranges from 25,917.06 to 67,299.77, while the Shannon and Simpson indexes are 2.45-4.53 and 0.03-0.30, respectively (see Table S3), indicating a relatively large variation in microbial diversity. The MannWhitney $\mathrm{U}$ test was performed to compare the diversity indexes, as the sample is small $(<30)$, and $p<0.1$ was interpreted to be statistically significant.

According to the ACE and Shannon indexes, the total number of the archaeal taxa of samples L10 and L50 are greater than those of the bacterial taxa, respectively, and the diversity of the archaea taxa is greater than that of the bacteria for the other four samples, except for L10 (see Table S3). Samples L08 and L10 are richer in archaea taxa, while the other three samples are more abundant in bacterial taxa (see Table S3). With respect to bacterial communities, sample L08 has the highest richness but the lowest diversity, while sample L10 has the lowest richness but the highest diversity. In the archaea communities, sample L10 has the highest richness, while sample L01 has the lowest richness, sample L50 has the highest diversity, and sample L08 has the lowest diversity. However, no significant difference exists in the ACE index between the archaeal and bacterial communities ( $p=0.310$, both for ACE), whereas the difference in the Shannon index is significant $(p=0.095)$. The variation in microbial richness and diversity reflects the spatial heterogeneity of physicochemical conditions typical in geothermal systems.

\section{Conclusions}

Both the bacterial and archaeal community compositions of the thermal waters from the Lindian geothermal field were investigated and accounted for $68 \%$ and $32 \%$, on average, of the microbial taxa, respectively. The proportion of archaeal taxa is far higher than other thermal waters reported, and the microbial richness is remarkedly high, which can be related to the high organic matter content and methanogenesis in the geothermal reservoir.

The existence of methanogens indicates a strong reducing groundwater environment in the geothermal reservoir. The prediction of microbial community function shows that the 
main function of bacteria is to decompose macromolecular organic matter into substrates facilitating methanogens, while the main function of the archaea is to produce methane through $\mathrm{CO}_{2}$ reduction by $\mathrm{H}_{2}$, indicating that hydrogenotrophic methanogenesis is the primary pathway of methane production in the Lindian geothermal field.

Supplementary Materials: The following supporting information can be downloaded at: https: / / www.mdpi.com/article/10.3390/w14040632/s1, Table S1: OTU and taxonomy of archaea; Table S2: OTU and taxonomy of bacterial; Table S3: Diversity of archaeal and bacterial communities of the thermal waters; Figure S1: Phylum level bar chart for bacterial taxa; Figure S2: Phylum level bar chart for archaeal taxa.

Author Contributions: Conceptualization and methodology, Y.S. (Yujuan Su), F.Y., X.Z. and D.L.; investigation and analysis, Y.S. (Yujuan Su), F.Y., D.L., X.Z. and Y.M.; data curation, D.L., Y.S. (Yujia Shi), J.D. and X.W.; writing-original draft preparation, Y.S. (Yujuan Su), F.Y., T.Z. and D.L.; writingreview and editing, F.Y., Y.S. (Yujuan Su) and L.L. All authors have read and agreed to the published version of the manuscript.

Funding: This research was financially supported by NSFC (No. 41202167).

Data Availability Statement: All data are reported here and the raw sequencing data are available from the authors upon request.

Acknowledgments: Thanks for the help of the office of geothermal resources development and utilization of Lindian County during the field investigation. This work is supported by the National Natural Science Foundation of China (Youth) Project (No. 41202167).

Conflicts of Interest: The authors declare no conflict of interest.

\section{References}

1. Ai, M.Q. Microbial Community Structure of Produced Water in Daqing Oilfield. Master's Thesis, University of Chinese Academy of Sciences, Beijing, China, 2010.

2. Zheng, X.H.; Duan, C.Y.; Xia, B.R.; Jiang, Y.; Wen, J. Hydrogeochemical modeling of the shallow thermal water evolution in Yangbajing geothermal field, Tibet. J. Earth Sci. 2019, 30, 870-878. [CrossRef]

3. Brock, T.D. (Ed.) Thermophiles: General, molecular, and applied microbiology. In Wiley Series in Ecological and Applied Microbiology; John Wiley and Sons: Hoboken, NJ, USA, 1986.

4. Kristjánsson, J.K.; Hreggvidsson, G.O. Ecology and habitats of extremophiles. World J. Microbiol. Biotechnol. 1995, 11, 17-25. [CrossRef] [PubMed]

5. Houghton, K.M.; Carere, C.R.; McDonald, I.R. Thermophilic methanotrophs: In hot pursuit. FEMS Microbiol. Ecol. 2019, 95, fiz125. [CrossRef] [PubMed]

6. $\quad$ Ross, N.; Villemur, R.; Deschênes, L.; Samson, R. Clogging of a limestone fracture by stimulating groundwater microbes. Water Res. 2001, 35, 2029-2037. [CrossRef]

7. Li, C.Y.; Zhong, S.; Zhang, F.J.; Wang, Z.; Jiang, F.H.; Wan, Y.Y. Response of microbial communities to supercritical $\mathrm{CO}_{2}$ and biogeochemical influences on microbially mediated $\mathrm{CO}_{2}$-saline-sandstone interactions. Chem. Geol. 2017, 473, 1-9. [CrossRef]

8. Hanson, C.A.; Fuhrman, J.A.; Horner-Devine, M.C.; Martiny, J.B.H. Beyond biogeographic patterns: Processes shaping the microbial landscape. Nat. Rev. Microbiol. 2012, 10, 497-506. [CrossRef]

9. Nemergut, D.R.; Schmidt, S.K.; Fukami, T. Patterns and processes of microbial community assembly. Microbiol. Mol. Biol. Rev. 2013, 77, 342-356. [CrossRef]

10. Power, J.F.; Carere, C.R.; Lee, C.K.; Wakerley, G.L.J.; Evans, D.W.; Button, M.; White, D.; Climo, M.D.; Hinze, A.M.; Morgan, X.C.; et al. Microbial biogeography of 925 geothermal springs in New Zealand. Nat. Commun. 2018, 9, 2876. [CrossRef]

11. Goldscheider, N.; Hunkeler, D.; Rossi, P. Review: Microbial biocenoses in pristine aquifers and an assessment of investigative methods. Hydrogeol. J. 2007, 14, 926-941. [CrossRef]

12. Griebler, C.; Lueders, T. Microbial biodiversity in groundwater ecosystems. Freshw. Biol. 2009, 54, 649-677. [CrossRef]

13. Gregory, S.P.; Maurice, L.D.; West, J.M.; Gooddy, D.C. Microbial communities in UK aquifers: Current understanding and future research needs. Q. J. Eng. Geol. Hydrogeol. 2014, 47, 145-157. [CrossRef]

14. Sirisena, K.A.; Daughney, C.J.; Moreau-Fournier, M.; Ryan, K.G.; Chambers, G.K. National survey of molecular bacterial diversity of New Zealand groundwater: Relationships between biodiversity, groundwater chemistry and aquifer characteristics. FEMS Microbiol. Ecol. 2013, 86, 490-504. [CrossRef] [PubMed]

15. Yeonghee, A. Ecology of groundwater microorganisms in aquifers. J. Life Sci. 2017, 27, 1086-1095.

16. Blank, C.E.; Cady, S.L.; PACE, N.R. Microbial composition of near-boiling silica-depositing thermal springs throughout Yellowstone National Park. Appl. Env. Microbiol. 2002, 68, 5123-5135. [CrossRef] 
17. Aditiawati, P.; Yohandini, H.; Madayanti, F.; Akhmaloka. Microbial diversity of acidic hot spring (Kawah Hujan B) in geothermal field of Kamojang area, west Java-Indonesia. Open Microbiol. J. 2010, 3, 58-66. [CrossRef]

18. Shen, J.H.; Song, W.Z.; Lin, X.Z.; Wang, S. Analysis of archaea diversity in Padang Cermin thermal spring, Indonesia. Prog. Mar. Sci. 2012, 30, 534-540.

19. Song, Z.Q.; Chen, J.Q.; Zhi, X.Y.; Huang, Z.Y.; Zhang, C.L.; Li, W.J.; Li, W.J. Preliminary analysis on diversity and phylogeny of archaea from Liangrequan, Tengchong. Chin. J. Microbiol. 2008, 35, 372-377.

20. Jiang, Z. Environmental Aiogeochemistry of Arsenic in Tengchong Geothermal Area. Ph.D. Thesis, China University of Geosciences, Beijing, China, 2016.

21. Lynne, B.Y.; Campbell, K.A. Diagenetic transformations (opal-A to quartz) of low- and mid-temperature microbial textures in siliceous hot-spring deposits, Taupo Volcanic Zone, New Zealand. Can. J. Earth Sci. 2003, 40, 1679-1696. [CrossRef]

22. Zhang, D.K. Accumulation Conditions and Potential of Water-Soluble Gas Resources in Lindian Area of Songliao Basin. Master's Thesis, Jilin University, Changchun, China, 2009.

23. Wang, J. Enrichment Conditions and Resource Potential of Water-Soluble Gas in Northern Songliao Basin. Master's Thesis, Northeast Petroleum University, Daqing, China, 2017.

24. Ding, A.; Song, G.X.; Hui, Y.G.; Lu, S.F. Distribution and geochemical significance of acidic oxygen-containing compounds in biogas source rocks in Binbei area, Songliao Basin. Nat. Gas Geosci. 2004, 15, 51-57.

25. Chi, Y.L. Formation Mechanism of Deep Natural Gas in Northern Songliao Basin. Ph.D. Thesis, Changchun University of Science and Technology, Changchun, China, 2000.

26. Fournier, R.O. Chemical geothermometers and mixing models for geothermal systems. Geothermics 1997, 5, 41-50. [CrossRef]

27. Su, Y.J. Genesis and Rational Development of Typical Geothermal Field in the Songliao Basin: A Case Study of Lindian Geothermal Field. Ph.D. Thesis, Jilin University, Changchun, China, 2021.

28. Temizel, E.H.; Gültekin, F.; Ersoy, A.F. Major, trace, and rare earth element geochemistry of the Ayder and İkizdere (Rize, NE Turkey) geothermal waters: Constraints for water-rock interactions. Geothermics 2020, 86, 101810. [CrossRef]

29. Vinnarasi, F.; Srinivasamoorthy, K.; Saravanan, K.; Gopinath, S.; Prakash, R.; Ponnumani, G.; Babu, C. Rare earth elements geochemistry of groundwater from Shanmuganadhi, Tamilnadu, India: Chemical weathering implications using geochemical mass-balance calculations. Geochemistry 2020, 80, 125668. [CrossRef]

30. Wang, M.M.; Zhou, X.; Liu, Y.; Xu, H.F.; Wu, Y.Q.; Zhuo, L.Y. Major, trace and rare earth elements geochemistry of geothermal waters from the Rehai high-temperature geothermal field in Tengchong of China. Appl. Geochem. 2020, 119, 104639. [CrossRef]

31. Wang, Z.G.; Yu, X.Y.; Zhao, Z.H. Rare Earth Element Geochemistry; Science Press: Beijing, China, 1989. (In Chinese)

32. Fan, M.M. Comparative Metagenomic Analysis of Microbial Communities in Geothermal Environments with Different Temperatures and pH Values. Master's Thesis, University of Chinese Academy of Sciences, Beijing, China, 2016.

33. Mehetre, G.T.; Paranjpe, A.; Dastager, S.G.; Dharne, M.S. Investigation of microbial diversity in geothermal hot springs in Unkeshwar, India, based on 16S rRNA amplicon metagenome sequencing. Genome Announc. 2016, 4, e01766-15. [CrossRef]

34. Davidova, I.A.; Gieg, L.M.; Duncan, I.C.E. Anaerobic phenanthrene mineralization by a carboxylating sulfate-reducing bacterial enrichment. ISME J. 2007, 1, 436-442. [CrossRef] [PubMed]

35. She, Y.H.; Zhang, X.L.; Zhang, F.; Wang, L.H.; Zhao, L.P. Molecular analysis of microbial community in water drive reservoir of Dagangkongdian oilfield. Acta Microbio. Sinica. 2005, 45, 329-334.

36. She, Y.H. Study on the Mechanism of Enhancing Oil Recovery by Microbial Resources. Ph.D. Thesis, Wuhan University, Wuhan, China, 2010.

37. Baker, B.J.; De Anda, V.; Seitz, K.W.; Dombrowski, N.; Santoro, A.E.; Lloyd, K.G. Diversity, ecology and evolution of Archaea. Nat Microbiol. 2020, 5, 887-900. [CrossRef]

38. Zhao, J.Y.; Zhen, S.J.; Zhang, C.Y.; Yin, M.Y.; Zhang, S. Composition and functional prediction of microbial communities in deep geothermal water from Jizhong (Central Hebei) geothermal area. Acta Geoscientica Sinica 2021, 42, 605-616.

39. Sun, X.X.; Jiang, H.C. Research progress in the nitrification process of lake microorganisms. J. Microbiol. 2020, 60, 1148-1161.

40. Russell, M.; Martin, W. The rocky roots of the acetyl-CoA pathway. Tends Biochem. Sci. 2004, 29, 358-363. [CrossRef]

41. Chatterjee, B.; Mazumdar, D. Anaerobic digestion for the stabilization of the organic fraction of municipal solid waste: A review. Environ. Rev. 2016, 24, 426-459. [CrossRef]

42. Zhang, J.C.; Xu, Y.Q.; Lu, Y.H. Microbial mechanism of methane production and oxidation in terrestrial ecosystem. Acta Ecol. Sin. 2015, 35, 6592-6603.

43. Etiope, G.; Sherwood-Lollar, B. Abiotic methane on Earth. Rev. Geophys. 2013, 51, 276-299. [CrossRef]

44. Davis, K.J.; Lu, S.P.; Barnhart, E.P.; Parker, A.E.; Fields, M.W.; Gerlach, R. Type and amount of organic amendments affect enhanced biogenic methane production from coal and microbial community structure. Fuel 2018, 211, 600-608. [CrossRef]

45. Zhao, J.Y. Study on Spatial Structure and Hydrothermal Differentiation Process of Deep Geothermal Reservoir in Xiongan New Area. Ph.D. Thesis, Chinese Academy of Geological Sciences, Beijing, China, 2020.

46. Chiriac, C.M.; Baricz, A.; Szekeres, E.; Rudi, K.; Dragos, N.; Coman, C. Microbial composition and diversity patterns in deep hyperthermal aquifers from the Western Plain of Romania. Microb. Ecol. 2018, 75, 38-51. [CrossRef] [PubMed]

47. Rupasinghe, R.; Amarasena, S.; Wickramarathna, S.; Biggs, P.J.; Chandrajith, R.; Wickramasinghe, S. Microbial diversity and ecology of geothermal springs in the high-grade metamorphic terrain of Sri Lanka. Environ. Adv. 2022, 7, 100166. [CrossRef] 
48. Reysenbach, A.L.; Shock, E. Merging genomes with geochemistry in hydrothermal ecosystems. Science 2002, 296, 1077-1082. [CrossRef]

49. Zhang, M. Metagenomic Study on the Structure and Function of Microbial Communities in Sediments and Deep Groundwater of the High Arsenic Aquifer in Yinchuan. Master's Thesis, Harbin Institute of Technology, Harbin, China, 2020. 